\title{
Towards the De-secularisation of Heritage
}

\author{
Gamini Wijesuriya \\ International Centre for the Study of Preservation and Restoration of Cultural Property (ICCROM), Rome, Italy \\ Email: gw@iccrom.org
}

\begin{abstract}
This paper argues that modern conservation concepts, as portrayed in documents like the Venice Charter, have led to the 'secularisation' of built heritage. The term 'secularisation' is used to describe the over-emphasis on materiality that has led to it being distanced from people. The main focus of this approach has been on the well-being of the material contents of heritage. The reason for this can be attributed to the fact that conservation philosophy in its formative stages was rooted in the contemporary secular values of the Western world. The paper discusses secularisation and its consequences, resistance to change and its authority or dominance in conservation practice. Despite this dominance and authority, the paper argues that changes which focus on people have happened, particularly, over the last two decades. These changes are characterised as the de-secularisation of heritage. Such changes can also be read as a paradigm shift of moving from the care of heritage to that of pursuing the wellbeing of both heritage and society as a whole. While providing some sources that can sustain de-secularisation, the paper argues that this shift is a sine qua non for heritage to be meaningful and also to act as a cultural motivator for development.
\end{abstract}

KEYWORDS secularisation, conservation, management, heritage

Received April 3, 2017; accepted May 30, 2017.

\section{Introduction}

Built heritage can be a cultural motivator for urban and rural development. Yet, there are certain stumbling blocks to realising this. The first stumbling block is the overemphasis on materiality that has led to its being distanced from spirituality and other concerns of people. This is characterised as secularisation ${ }^{1}$. This will be dealt with in the first part of this paper highlighting the ignorance of all values thereby distancing heritage from the society. The second stumbling block is the resistance to change despite demand, and the authority or dominance by those who strongly promote the secularisation-led approaches which will be discussed in part two of this paper. Over the decades, these two stumbling blocks have hindered the development of a much needed broader theoretical and practical basis for more appropriate approaches to conservation and management. The third part of the paper shows that, despite the authority and dominance of secularisation, changes have happened within the heritage sector. In this paper, these are characterised as de-secularisation. This can be seen in the two decades starting from mid 1990s.
Some of the key changes evident will be discussed in this part of the paper. The focus of these changes aimed at understanding heritage in a more holistic manner, capturing all values and recognising the dynamic relationship that exists between people and heritage. These changes, the paper argues, are tantamount to a paradigm shift in conservation that focuses not only on the well-being of heritage but also on the well-being of the people. Some work being done to sustain de-secularisation led changes are presented towards the end of the paper.

A word on sources for this paper. The idea of secularisation was first presented at an International Symposium held in Thailand in October 2016 (Wijesuriya, 2016a) as part of a keynote presentation by the author titled 'From Venice Charter to Nara Plus 20'. This was further developed as part of a keynote address 'Global Trends in Human Resources Development for Protection of Cultural Heritage' presented at an international seminar held in December 2016 in Nara, Japan (Wijesuriya, 2016b). The latter also deals with trend setters that are responsible for changes in approaches to the protection of cultural 


\section{CONSERVATION OF MONUMENTS \& SITES}

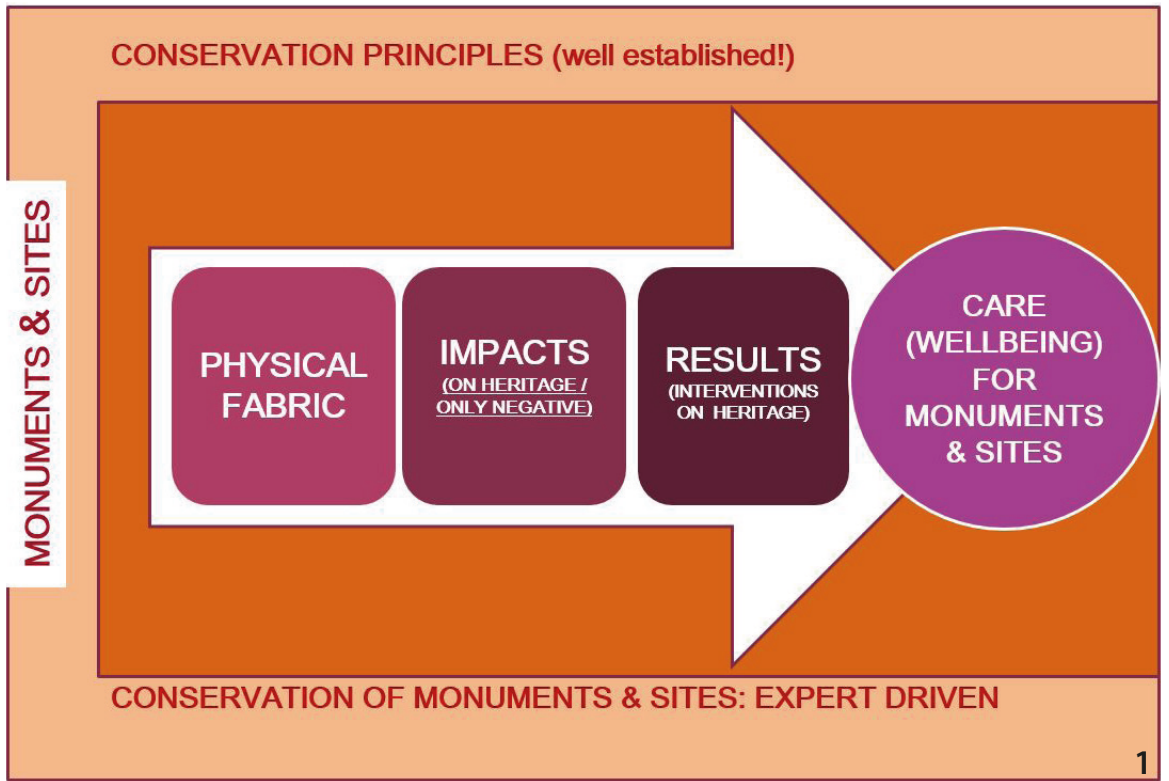

Figure 1 Approach to Conservation of Monuments and Sites (Source: Wijesuriya 2016b). heritage which are worth mentioning briefly. The key trend setter referred to in this paper is UNESCO and its World Heritage process. UNESCO is supported by its own direct creation ICCROM (1956) and indirect creation ICOMOS (1965). These changes are also supported by a variety of other institutions such as UNESCO Category Two Centres (e.g. the World Heritage Institute of Training and Research in the Asia Pacific, WHITRAP) and Universities. There are other regional inter-governmental institutions like the European Commission engaged in these processes. Some of the initiatives led by individual countries also have contributed to the changes and new trends.

The discussion of overemphasis on materiality by the Venice Charter-led conservation approach may seem relatively old, but should be considered not as a criticism against it but as an element of progresses towards a more globally acceptable heritage discourse. The most fundamental message of this paper is that conservation principles are still evolving and in the process, some of the gaps that existed in the past are being addressed. On the other hand, there is a need to revive the discussion when considering its dominance, as exemplified in this paper such as Ayutthaya.

\section{The Secularisation of Heritage}

The conservation approach promoted by documents like the Venice Charter is elsewhere identified as the Conventional Conservation Approach (Wijesuriya 2010) and can be graphically illustrated through Figure 1 (Wijesuriya 2016b). It originates from concerns for monuments and sites. Through the conservation processes, the condition or the health of the fabric is examined and attempts are made to prolong its life. For this purpose, various interventions such as restoration are proposed. The overall goal of this approach can be interpreted as the well-being of monuments and sites. This was an approach exclusively led by 'experts'. However, despite criticisms, this approach is widely recognised even today as having laid the foundation for modern conservation discourse and has been disseminated globally.

However, many questions have been raised about the validity of applying a 'one size fits all' theory (Ndoro et.al 2015) and on other shortcomings. This paper focuses on one shortcoming which is the secularisation of heritage. The term used here is 'heritage' instead of 'monuments and sites', which entered into the discourse at a later stage. It should be noted that the secularisation-led process retained its dominance and authority over 'heritage' as well. Some may question the political correctness of the term secularisation and may even prefer in certain political contexts, a discussion on it. This is beyond the scope of this paper.

The term 'secularisation of heritage' is used to describe the phenomenon of the separation or distancing between materiality (i.e. the fabric of the sites) and spirituality (i.e. the concerns of the people connected to sites) and the overemphasising the importance of the former (Wijesuriya 2016a). The overemphasis on materiality or the fabric is evident in early conservation principles that focus on 
retrieving the aesthetic and historic values of heritage. For instance, according to the Venice Charter, the aim of restoration is to preserve and reveal aesthetic and historic values of the monument (ICOMOS 1964) paying less attention to other values such as spirituality. This was also supported by the widely recognised theory of restoration by Cesare Brandi, which argues that 'Restoration consists of the methodological moment in which the work of art is recognized in its physical being and in its dual aesthetic and historical nature, in view of its transmission to the future.' (Brandi, 2005) One of the consequences was the separation imposed between materiality and other values to people. One would argue that this was due to the fact that conservation philosophy in its formative stages was rooted in the secular values of European society. Regardless of their wider spectrum of values, monuments and sites became listed buildings to be conserved or as places for tourist attraction or even parks devoted to leisure and education. Ironically, heritage practitioners were compelled to focus only on the material side or the condition of the fabric, which could be interpreted as taking care exclusively of the body and ignoring the soul. Furthermore, questions were never raised about 'which history' or 'which aesthetics' should be revealed.

When attempts were made to apply these principles in different countries and in diverse cultural contexts, heritage practitioners were confronted with challenges. A case in point was living heritage sites, which continue to perform the function for which they were originally created. Continuity of the function in such places became more important than the historic and aesthetic values. However, any actions focusing beyond materiality were considered as violating modern conservation principles.

For the purpose of this discussion, it should be mentioned that these secularisation principles were developed and propagated while overlooking the discussions taking place on non-material values. For instance, the participants of the Madrid Conference in 1904 defined a category called 'living monuments, i.e. those which continue to serve the purposes for which they were originally intended' (The Architectural Journal 1904). The conference also resolved that such monuments need different treatments which contradicts the classical definitions of restoration. In 1923, John Marshall identified the same category in India and insisted on different treatment. Accordingly, 'In the case of living monuments it is sometimes necessary to restore them to a greater extent than would be desirable on purely archaeological grounds...' (Marshall 1923). As far back as 1945, Sri Lanka had adopted principles for restoration that respect spiritual values which stated, 'restoration of ancient shrines ... has to be carried out without hurting the religious susceptibilities of the people ... that intervention by the Department (government) does not affect their vested interests and traditional rights... (Paranavitana 1947).

It is important to note that reference to 'spiritual' aspects has existed in the original preface of the Venice Charter, drafted in French by the former Director of ICCROM. Jokilehto (2015) has translated it as follows:

Charged with a spiritual message from the past, the monumental achievements of the people offer to the present day a living witness of their age-old traditions. Humanity, which is becoming day by day more conscious of the unity of human values, regards them as a common heritage, and, in view of the future generations, accepts a joint responsibility for their safeguarding. It feels as a duty to hand them on in the full richness of their authenticity (Jokilehto, 2015).

However, the word 'spiritual' has disappeared from the popular English version now widely used. It starts 'imbued with 'a message from the past...' (ICOMOS 1964).

The development of urban conservation is attributed to the second half of the $20^{\text {th }}$ century (Bandarin et al. 2012) but under the influence of the modern conservation principles described above. As a result, urban conservation also focused more on materiality and not much on the concerns of people. This characterises the phenomenon of the secularisation. This too happened, while there was earlier evidence against such phenomenon. For instance, Giovannoni from Italy has argued, 'against museum-like freezing of historic centres, a common practice at the time in Italy and other countries, consisting of isolation of historic fabric from contemporary life, and the creation of a specialized district used for tourism purpose' (Bandarin et.al. 2012). The need to recognise 'human activities' as an integral part of heritage in historic areas also appeared in the 'International Recommendation Concerning the Safeguarding and Contemporary Role of Historic Areas' (UNESCO 1976).

The ignorance of all values and as a result, distancing of heritage from society are intertwined. Many examples can be quoted to prove this. Dombashave cave in Zimbabwe (Ndoro et al. 2003) was declared a national monument for its rock art. However, the place has three key elements: rock art, sacred forest and rain making ceremony. The overemphasis on materiality forced the authorities to focus only on rock art and to ignore other values which 

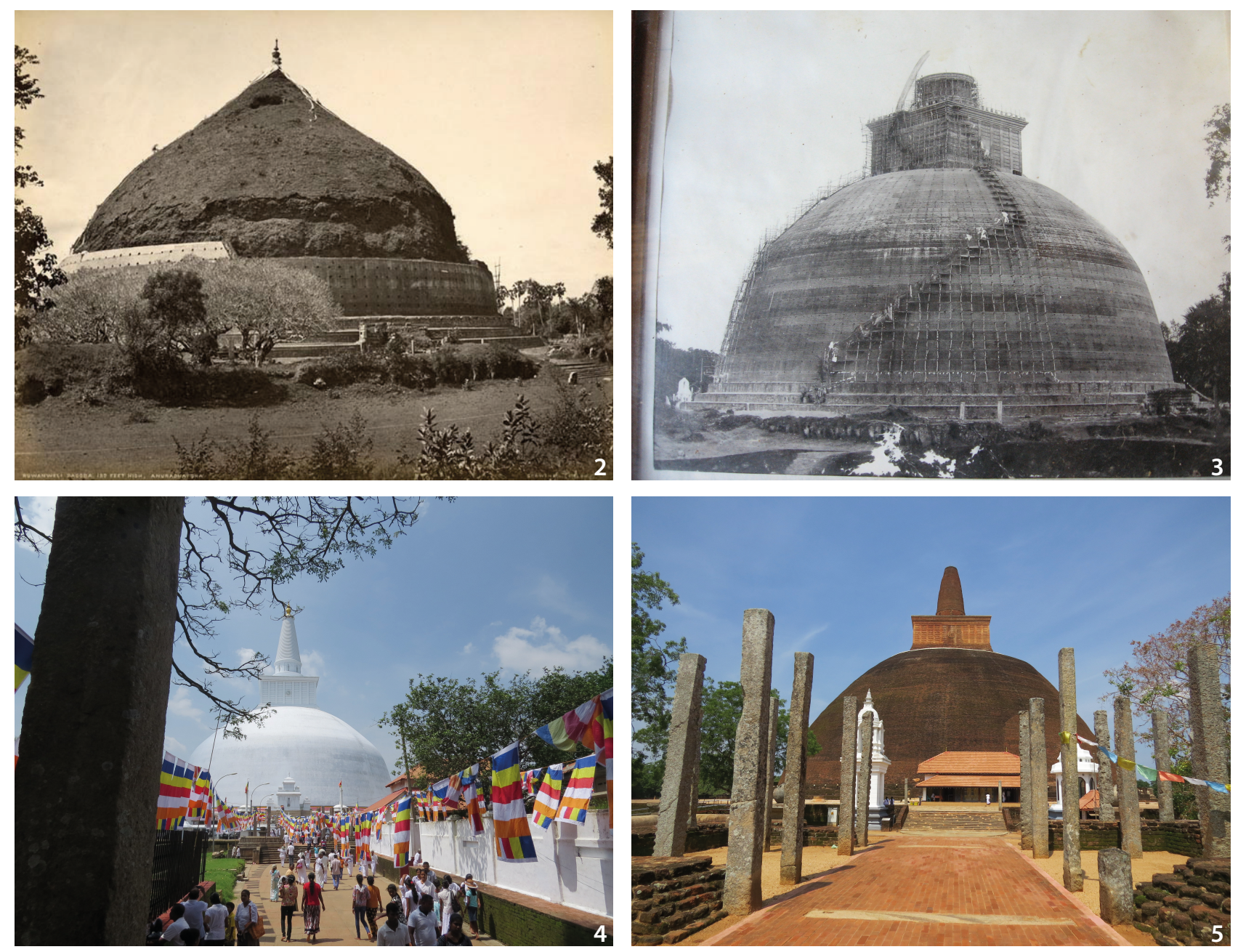

Figure 2 Ruwanweli Stupa (built in $1^{\text {st }}$ century BC abandoned during the colonial occupation) (Source: Department of Archaeology, Sri Lanka). Figure 3 Ruwanweli Stupa being restored 1940 (Source: Department of Archaeology, Sri Lanka). Figure 4 Ruwanweli Stupa at present (Source: Nilan Cooray).

Figure 5 Abhayagiri Stupa (built in $1^{\text {st }}$ century BC) at present (Source: Nilan Cooray).

were at the heart of people. Communities struggled to gain their values but failed. As a result, they not only were distanced from heritage but eventually destroyed the rock art as they were considered the barrier for recognising their values. Stupas in Sri Lanka represent some of the largest brick structures ever created by humanity starting from the $3^{\text {rd }}$ century BC. As much as they were brick mounds, they were also sacred objects of worship. There is a strong symbolic values that attracts people to perform religious acts and festivals. Due to colonial the occupation over more than 450 years, most of them fell into ruin condition. Some of them are still in ruined condition, while some have been restored by communities to regain their original appearance and the symbolic values so that their rituals can be performed (Figure 2-4). Some of them are still left in ruined condition following modern conservation principles (Figure 5). In a full moon day when people perform religious activities, those that have been restored attract millions, while others attract only considerably low numbers.

\section{The Authority of Secularisation}

This chapter is an attempt to discuss the dominance and the authority of the secularisation and its resistance to change. The demand for changes came from many fronts and from national to international level. This is best exemplified from the life of the Venice Charter. An Asian voice, Roland Silva, who later became the President of ICOMOS International (1990-1999), appreciated the positive aspects of the Charter while also highlighting the gaps and stated that '...the Venice Charter itself is not necessarily the end of the road. We have shown the scope ... and limitation which we have either to correct or to combat' (Silva 1983).

In order to celebrate the $25^{\text {th }}$ anniversary of the Venice Charter at the $9^{\text {th }}$ General Assembly held in Switzerland in 
1990, ICOMOS National Committees were asked to submit proposals for revisions or changes to the Charter. The National Committees, especially those from outside Europe, felt that there was a need for revision. Several of the comments are worth quoting. ICOMOS Australia commented that '...concept of anastylosis best exemplifies the European nature of the conservation philosophy, ... and this is the procedure adopted by archaeologists in dealing with the ruins of classical temples and similar monuments' (ICOMOS 1990). They also commented that 'The Charter's text, although concise and clear, is insufficient due to scientific progress having broadened the field of work in preservation and restoration, making it, thereby, necessary to revise concepts and demand effective and not just formal participation of specialists in areas of modern development.' (ICOMOS 1990)

ICOMOS US commented that the 'literal implementation of all its articles in the US would be difficult today and indeed raised many issues why its contents should be revisited ... the social utility of historic preservation in dealing with such problems as poverty and economic development' (ICOMOS 1990).

Despite these concerns, the participants of the $9^{\text {th }}$ General Assembly resolved that 'The Charter [of Venice] is a living and dynamic document which for more than a quarter of a century has guided the actions of those responsible for preservation of monuments and sites throughout the world ... And the Charter of Venice is a historical monument which should be protected and preserved. It needs neither restoration, renewal, nor reconstruction. The Charter should be considered in a philosophical and open perspective rather than in a narrow technical one.' (ICOMOS 1990)

Although the group meeting in 1990 resisted changes, some of the original authors of the Venice Charter themselves began to express the inadequacy of the document. At the pre-Nara meeting held in Norway in 1993, Raymond Lemaire, who was one of the leading personalities present at the meeting admitted that 'the congress participants in 1964 did not realise the complexity of international preservation, mainly because $95 \%$ of the participants were Europeans' (Larsen et al. 1994). In addition, the following comments made by him, although long, are reproduced below. They are self-explanatory and justify why a new document was necessary. They also explain the reluctance by some sections of the conservation community for change.

Charters are fashionable. They are considered to contribute to directing action. However, they never contain more than the minimum on which the majority has agreed. Only exceptionally do they cover the whole of the issue which concerns them. This is the case with the Venice Charter. It was drafted by a few specialists all sharing the same doctrinal views. Each one believed the philosophy and the ethic underpinning the text of the Charter to be a universal value, although of Western origin. Times have changed. Other cultures have earned respect and the differences which they represent in relation to those of the West have enriched the vision which humanity has of itself and of its culture ... Modernist interventions on old monuments have increased, using reference to the Charter, but how many errors have been perpetrated in its name! ... For various and wholly plausible reasons there is still strong reluctance within ICOMOS to engage in drafting a new doctrinal document or even to simply adjust the original text, as has been demonstrated in the various General Assemblies-Moscow 1978, Rome 1981, Lausanne 1990. Nevertheless, despite the delicacy of the task, it needs to be addressed with caution and wisdom, with respect for all cultures and above all with ethical and intellectual discipline (ICOMOS 1990).

Gertrude Tripp (ICOMOS) was another author of the Venice Charter who stated at a later stage that 'We imagined that our Carta del Restauro of 1964 would have universal significance ... However, today I can confess: there was much that we simply did not know. You know, we were convinced that we were sufficiently clever. But we did not understand where the difficulties were.' (ICOMOS 1990)

One can argue that ICOMOS has no legitimate right to revise or change the Venice Charter since it was not one of its products. However, the Second Congress of Architects and Specialists of Historic Building (1964) which drafted the Venice Charter acknowledged the need to revisit the contents of the Athens Charter (1931) for which they had no formal ownership. The group however, acknowledged (ICOMOS 1964) the need for a new guiding document and produced the Venice Charter. It could have been an approach for ICOMOS to follow in 1990, in order to address growing demands for change or to address gaps. Instead, ICOMOS promoted the creation of new charters on different themes and at national and international levels while maintaining the secularisation-led approaches. The Australia ICOMOS Burra Charter (1972) can be considered as an earlier attempt towards de-secularisation, thanks to its promotion of a values-led approach. With the exception of the Burra Charter and the New Zealand Charter, others have not been subjected to any revisions 

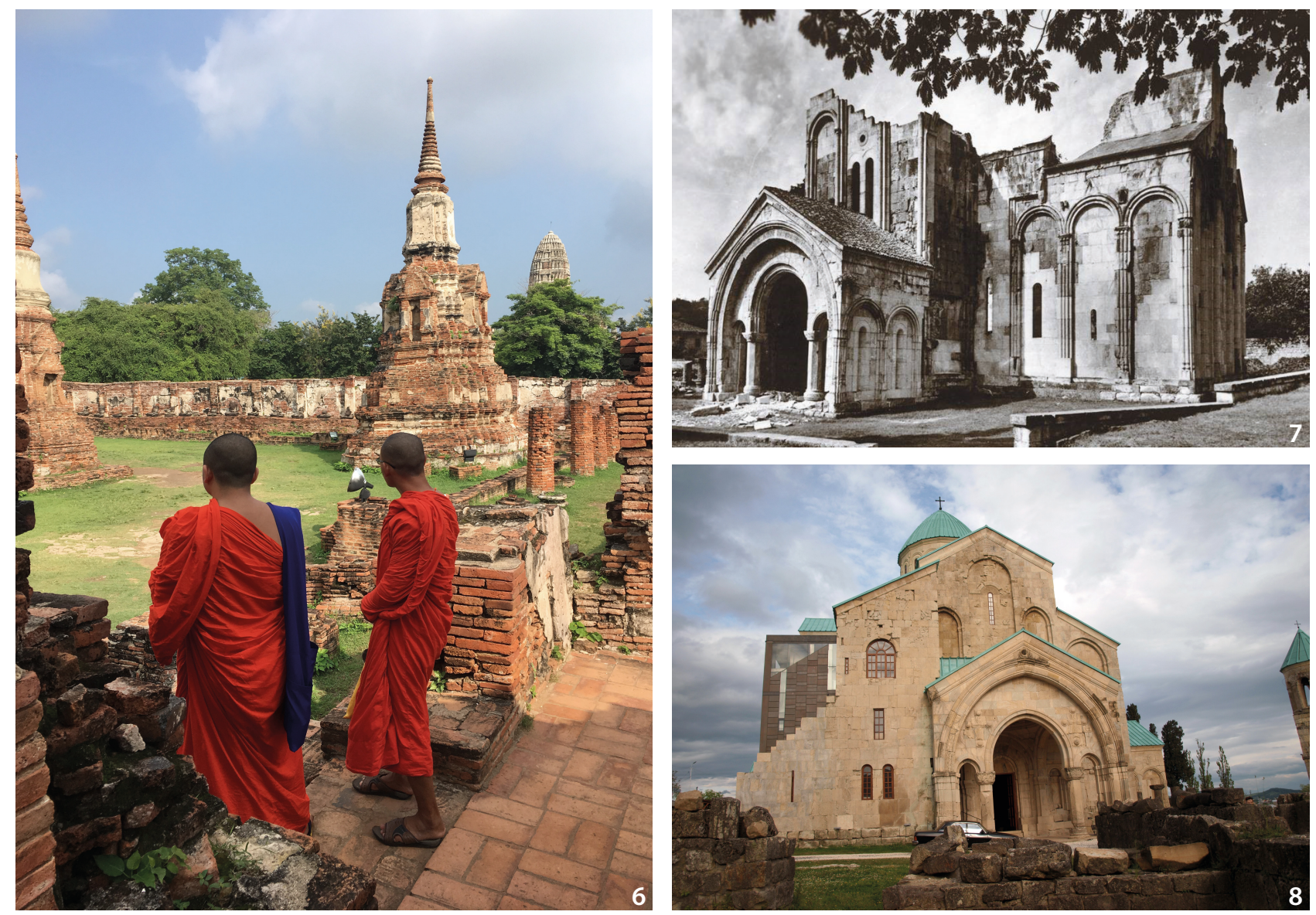

Figure 6 Ayutthaya (Source: the author).

Figure 7 Bagrati Cathedral in ruined condition (Source: National Agency for Cultural Heritage Preservation of Georgia).

Figure 8 Bagrati Cathedral after restoration (Source: Tamar Meliva Georgia).

or testing. Thus their rigor has not been questioned. This is perhaps the reason why Andrzej Tomaszewski (2007), who served as the Chair of the ICOMOS International Scientific Committee on Theory and Philosophy had to make the following comments about the charters in general: 'From the period between the two World Wars, we may observe a paucity of deeper-theoretical studies ... Instead of these, we have seen the creation of increasing numbers of documents concerning conservation, of very variable scientific potential ... As a rule, they contain empty desiderata presented for acceptance and use and not theoretical reflection. Philosophy and theory have been replaced by doctrine.' (Tomaszewski 2007)

Despite all these circumstances, the Venice Charter, which was intended to be a guiding document 'with each country being responsible for applying the plan within the framework of its own culture and traditions' (ICOMOS 1964) on a voluntary basis, consolidated its authority due to the World Heritage Convention. The responsibility vested in UNESCO to monitor World Heritage Sites is executed mainly by ICOMOS. In the absence of a robust theoretical and practical foundation to guide conservation, ICOMOS began to apply the contents of the Venice Charter through the World Heritage process. ICOMOS even reached the point of claiming that the Venice Charter is 'the foundation guiding document for the conservation of cultural heritage' (UNESCO et al. 2010), rather than acknowledging it as 'one of the key guiding documents' (UNESCO et al. 2011) thus demonstrating the authority of the secularisation-led approach.

There are many examples that reflect secularisation and its authority. One of them is the recent 'International Symposium on the Conservation of Brick Monuments at World Heritage Sites' held from 19-21 October 2016 at the Historic City of Ayutthaya World Heritage Site, Thailand. Ayutthaya is one of the most sacred sites for the Buddhist community in Thailand and neighbouring countries (Figure 6). It is a place of pilgrimage and a living religious site. The focus only on 'brick monuments' was a result of the secularisation and its authority. The secularisation issue was first raised by the author (Wijesuriya 2016a) in his keynote speech 'From the Charter of Venice to Nara Plus 20' at the symposium. 
The second example is the World Heritage Property of Bagrati Cathedral and Gelati Monastery of Georgia which consists of consisted of the two components; Bagrati Cathedral and Gelati Monastery. The cathedral was in a ruined condition at the time of inscription (Figure 7). However, due to its religious and cultural significance, it was reconstructed (Figure 8) for the purpose of using it for the function for which it was originally created. As a result, the World Heritage Committee on the advice of ICOMOS decided that the 'Bagrati Cathedral has been altered to such an extent that its authenticity has been irreversibly compromised and that it no longer contributes to the justification for the criterion for which the property was inscribed' (UNESCO 2013) and asked Georgia to remove this component from the property. This raises many issues related to the secularisation of heritage and also the fact that its authority has not ceased to exist.

\section{De-secularisation}

De-secularisation is about reconnecting or reestablishing the flouted linkages between materiality and spirituality or between heritage and people and easing the dominance or authority of secularisation. This chapter argues that desecularisation or changes are evident despite the resistance and authority mentioned above. The rise of these changes can be traced back to the mid-1990s. The driving forces behind some of the changes discussed in this paper are the founding key players of the Venice Charter, namely UNESCO, ICCROM and its current guardian ICOMOS in addition to various regional organisations and individual countries.

The Burra Charter of Australia (1979) began to focus on values thereby bringing the people factor into the discussion. This gradually led to the development of a valuesled approach to conservation (Wijesuriya et al. 2013). This is considered as a major paradigm shift. The term heritage has been popular since the UNESCO adopted the World Heritage Convention in 1972. However, one of the key landmarks relevant to this discussion is the Nara Document on Authenticity of 1994. This was developed with the participation of all of the above actors (UNESCO, ICOMOS, ICCROM) supported by the government of Japan. The document gained official status since its incorporation into the Operational Guidelines of the World Heritage Convention in 2005 (with some additional contributions from the Africa region). The meeting in Nara however, had little or no in-depth discussion on the meaning or the relevance of authenticity, but considered it as an opportunity to 'challenge conventional thinking in the conservation field, and debate ways and means of broadening our horizons to bring greater respect for cultural and heritage diversity to conservation practice' (ICOMOS 1994). The document moved beyond the total dependency and the authority of secularisation by introducing people-friendly themes like use, function, traditions, spirit and feeling. It consolidated the discussion on values and emphasized diversity and cultural context, all of which are people-focused themes. The way this appears to have eased the authority of the secularisation is best expressed by the current president of ICOMOS, Gustavo Araoz (2011). He says, 'The Eurocentric doctrinal foundation that had been developed for over two centuries to sustain its focus on materiality was effectively challenged in the Nara Document, which recognised for the first time that authenticity is a relative concept that depends on its socioeconomic context.' (Araoz, 2011)

Unlike the Venice Charter, the Nara Document was subject to regular reviews. The Nara Plus 10 meeting was held in 2004, the outcome of which was not appreciated by heritage practitioners who deal with tangible heritage. The meeting was attended by practitioners from both the tangible and intangible heritage sectors and the latter challenged the relevance of authenticity to living cultures which are continuously evolving and changing. The division between the two groups during the meeting can be considered as another missed opportunity for an in-depth discussion on authenticity and its relevance and applicability when dealing with living cultures. Neither the Nara Document nor the changes discussed in this chapter completely eliminated the authority of secularisation and this meeting was a good example to demonstrate this point.

The Nara Plus 20 meeting was held in 2014, with a view to celebrate and discuss the future of the Nara Document and the result was the Nara Plus 20 Document. While maintaining the spirit and to some extent strengthening the conclusions of the Nara Document, the new document highlighted five themes that deserve more discussions. The five themes are: (1) diversity of heritage processes; (2) implications of evolution of cultural values; (3) involvement of multiple stakeholders; (4) conflicting claims and interpretation; and (5) the role of cultural heritage in sustainable development. The people-focused nature of all five themes favours the de-secularisation attempts discussed in this section. However, by stating that more work is needed in all these five areas, the document delivered a strong message about the evolving nature of conservation principles and the fact that more work is needed. The Nara Plus 20 Document also questioned the validity and 
feasibility of developing international guidance for heritage conservation which is considered a context-dependent endeavour (JAPAN ICOMOS 2004).

ICCROM started a programme on Integrated Territorial and Urban Conservation (ITUC) in 1997. The Programme began to view heritage in a more holistic manner focusing on landscapes or larger territories and recognizing the dynamic relationship that exists between people and heritage. Its offspring, the Living Heritage Sites (LHS) Programme (2003-2010) took a completely novel approach to recognising and defining heritage by focusing on its living dimensions and moving towards a Living Heritage Approach for conservation and management.

A living heritage approach implies a focus on people both past and present and their cultural products and practices, both tangible and intangible, so that values and relationships are considered and maintained through the process of sustainable development, management and regeneration of heritage sites. This further implies recognition of the importance of both the living aspects of heritage (continuity), and the heritage components in a living environment (ICCROM 2005).

The living heritage (Wijesuriya 2014) is characterised as places that continue to perform the function for which they were originally created. This in turn represents the continuity of a connected community, continuity of cultural expressions and the continuity of care using traditional and established systems. This way of understanding heritage requires a new approach for its conservation and management. The Living Heritage Approach promoted for this purpose was based on the premise that people and cultural heritage are indivisible, hence there is a need to care for, or address the 'well-being' of both, contrary to the secularisation approach. The results of the LHS led to the development of ICCROM programme on PeopleCentred Approaches to Conservation which focuses on collective well-being of heritage and people. This shift has become a vehicle to overcome the deficiencies of the past where overly expert-led heritage activities unfolded in isolation from the wider concerns of society. In this context, the promotion of People-centred Approaches (PCA) for the conservation and management of heritage is considered a way of providing a theoretical basis to underpin future practices. Indeed, the core activity of ICCROM's PCA Programme has been a course launched to build capacity in this area among heritage practitioners which will be expanded in the next section of the paper.

The above focus on people has been further developed through various initiatives of the UNESCO World Heritage
Committee, to which ICCROM and ICOMOS contributed significantly. In 2007, the World Heritage Committee recognised 'Communities' as one of their strategic directions. Since then, many activities have been undertaken to promote communities' concerns and to consider their role within the World Heritage processes. For instance, the $40^{\text {th }}$ anniversary of the Convention (2012) was dedicated to the promotion of local communities and sustainable development. The Kyoto Vision, adopted at the concluding session of the anniversary celebrations concluded that 'only through strengthened relationships between people and heritage, based on respect for cultural and biological diversity as a whole, integrating both tangible and intangible aspects and geared toward sustainable development, will the "future we want" become attainable' (UNESCO 2012).

Another key initiative of the UNESCO World Heritage Committee in favour of de-secularisation was the emphasis placed on the sustainable development paradigm. This paradigm not only recognizes the dynamic relationship that exists between people and heritage but also promotes the idea that heritage should contribute to the well-being of the people. There were discussions on sustainable development within programmes like ITUC, LHS and PCA (mentioned above) as far back as 1997. However, sustainable development gained greater momentum through the World Heritage process, particularly with the development and adoption of the 'Policy for Integrating a Sustainable Development Perspective into the Processes of the World Heritage Convention' (2015). The goals of this policy are as follows: harness the potential of World Heritage to contribute to sustainable development; align conservation and management to sustainable development objectives; and, in the process not compromise heritage values (including Outstanding Universal Value). The policy focuses on the overarching principles of human rights, equity and sustainability through a long-term perspective. Some of the significant features are the following: to recognise the need to link biological diversity and local cultures; all sustainable development dimensions are equally important and interdependent; not all sustainable development dimensions will equally apply to all heritage sites (World Heritage Sites); need for capacity building to enable implementation; relevant to all heritage, and not simply World Heritage (UNESCO 2015).

The previously known three dimensions (Environmental, Social and Economic) of sustainable development have now been expanded to four by adding Peace and Security. Environmental sustainability focuses on protecting biological and cultural diversity and ecosystem services and 

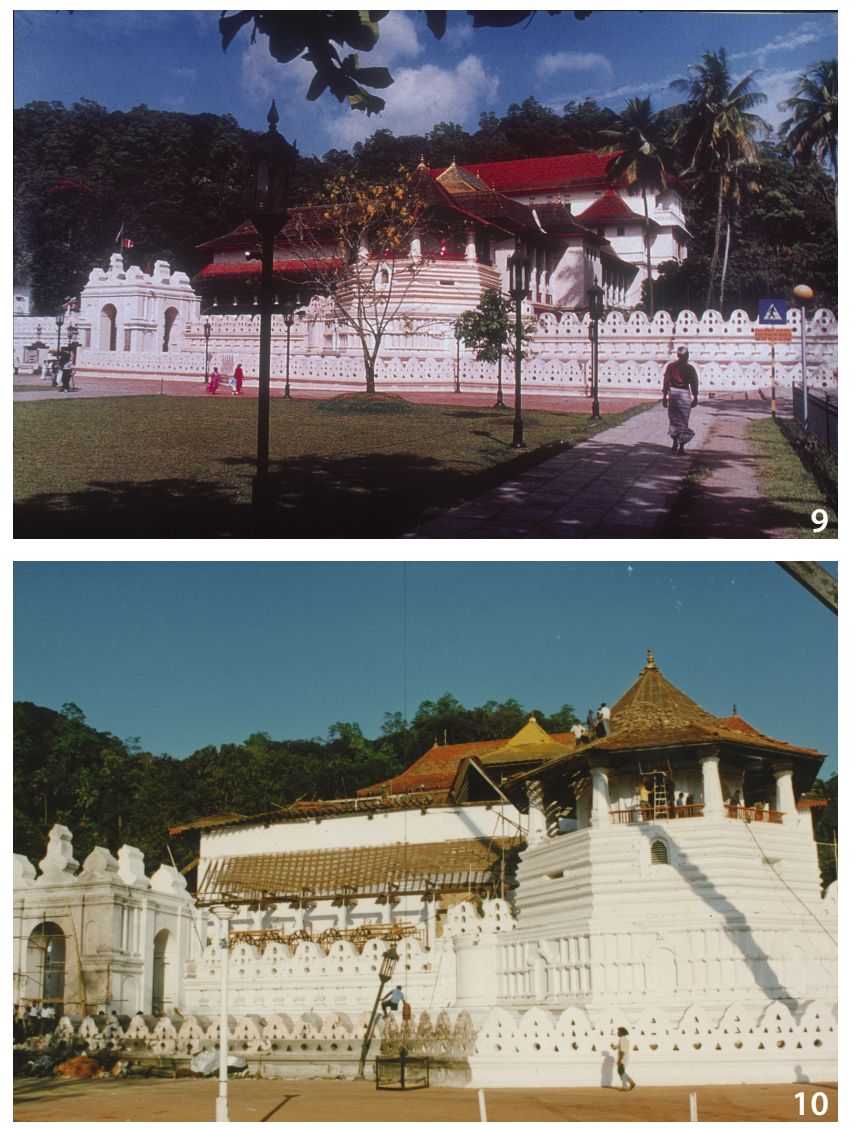

benefits; strengthening resilience to natural hazards and climate change. Inclusive social development focuses on contributing to inclusion and equity; enhancing the quality of life and well-being (through spiritual, aesthetic, scientific and educational values); respecting, protecting and promoting human rights; respecting, consulting and involving indigenous peoples and local communities; achieving gender equality. Inclusive economic development focuses on ensuring growth, employment, income and livelihoods; promoting economic investment and quality tourism; strengthening capacity-building, innovation and local entrepreneurship. Peace and security focuses on ensuring conflict prevention; protecting heritage during conflict; promoting conflict resolution; and contributing to postconflict recovery. Any efforts to promote these dimensions through heritage practices favours heritage as well as people thus contributing to the de-secularisation.

Interestingly, the policy was developed at the same time when the UN General Assembly adopted the Agenda 2030 or the 17 Sustainable Development Goals (and five 'Ps' namely People, Planet, Prosperity, Peace and Partnership) which seeks a better future for people and the planet. Heritage matters to society as a whole and, therefore, there is a strong call for the engagement of people in
Figure 9 Temple of the Tooth Relic-World Heritage Site (before bombing in 1998) (Source: the author). Figure 10 Temple of the Tooth Relic (bombed in 1998) (Source: the author).

Figure 11 Temple of the Tooth Relic after restoration (Source: the author).

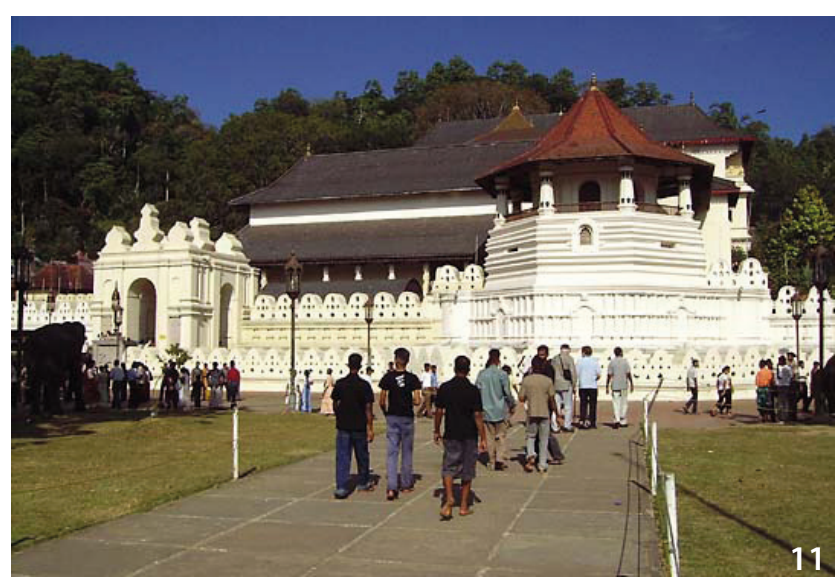

decision-making processes and for heritage to serve their wellbeing.

The UNESCO Recommendation on Historic Urban Landscapes adopted in 2014 has progressed beyond its early secularisation approach mentioned above. Article 11 of the Recommendation, below, is a good illustration of de-secularisation sentiments.

The historic urban landscape approach aims at preserving the quality of the human environment, enhancing the productive and sustainable use of urban spaces while recognizing their dynamic character, and promoting social and functional diversity. It integrates the goals of urban heritage conservation and those of social and economic development. It is rooted in a balanced and sustainable relationship between the urban and natural environment, between the needs of present and future generations and the legacy from the past (UNESCO 2011).

The focus on people discussed above, was seen as underpinning a series of initiatives undertaken in the last two decades globally, although no comprehensive analysis is given in this paper. However, the following is a good example of regional initiatives to illustrate other activities. 

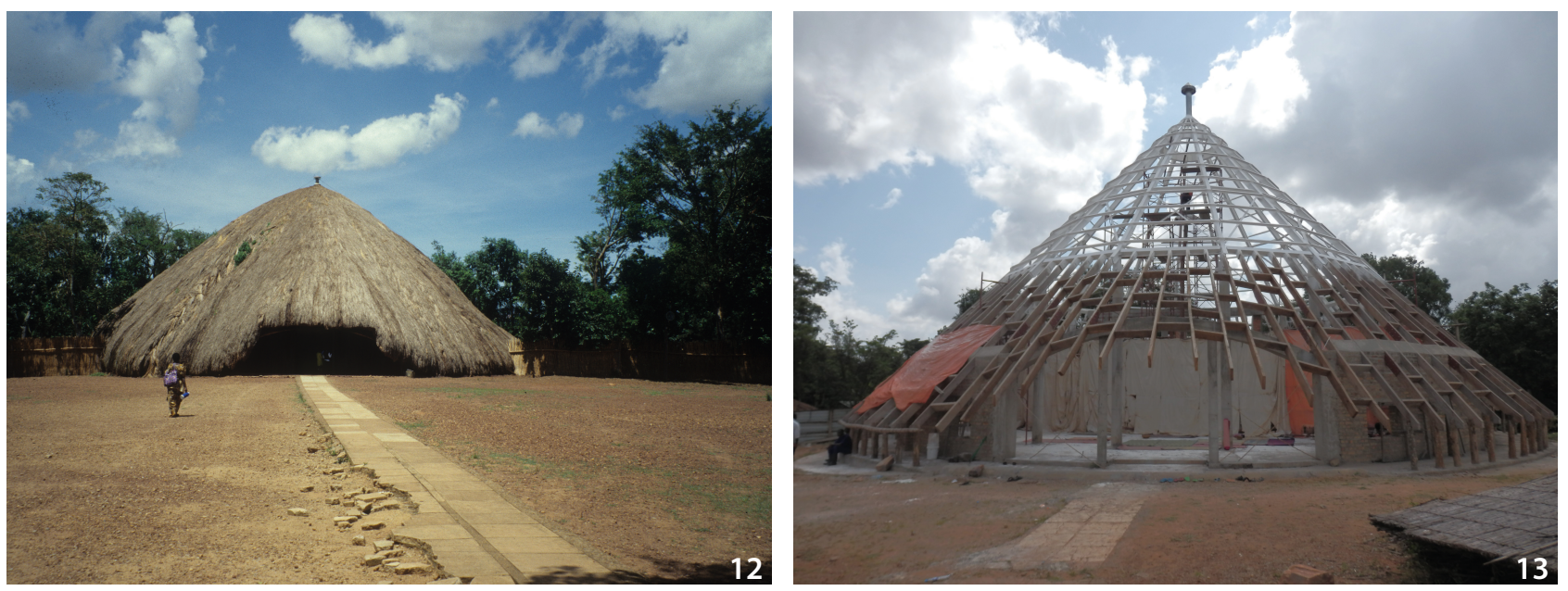

Figure 12 Kasubi Tomb, Uganda (Source: Joseph King).

Figure 13 Kasubi Tomb, being restored after destruction (Source: Joseph King).

In 2005, the Council of Europe Framework Convention on the Value of Cultural Heritage for Society (known as the Faro Convention) recognised the need to put people and human values at the centre of an enlarged and crossdisciplinary concept of cultural heritage', and emphasised 'the value and potential of cultural heritage wisely used as a resource for sustainable development and quality of life in a constantly evolving society' (Council of Europe 2005).

There are many examples in the world that are moving in this direction. The first World Heritage Site to be bombed by terrorists was the sacred Temple of the Tooth Relic in Sri Lanka in 1998 (Wijesuriya 2001, 2005). Complete restoration of the temple (Figure 9-11) started from the second day of bombing to regenerate the sacred atmosphere, revival of numerous rituals and practices attached to it. Communities contributed all funds required for the restoration purpose. There was hardly any space even for a discussion with the World Heritage Committee and its advisory bodies. Discussion of restoration of the Kasubi tomb of Uganda, another World Heritage sacred site destroyed in 2010, started immediately (Figure 12, Figure 13). The Boudhnatha stupa, destroyed by the earthquake in Kathmandu Valley in 2015, was immediately restored by the community regardless what is stated in the Operational Guidelines. All these are places with great spiritual and religious significance which benefits the society in numerous ways and supersedes their material contents.

To sum up this section, the de-secularisation of heritage can be explained in Figure 14 (Wijesuriya 2016b). The starting point is heritage (as against monuments and sites) and its integral component, people. The overall process is about managing heritage as against conservation.
The heritage process is to be governed by the two overarching principles formalised through the Nara Document, namely diversity and cultural context. Instead of fabric, the focus is on values which are held by people. Impacts on heritage and of heritage are assessed (positive and negative). Based on this assessment, desired results are elaborated to safeguard heritage and to ensure benefits are delivered to people. The final outcome expected is the well-being of society as well as the heritage thus linking the process with Sustainable Development goals. The process is about managing continuity (and change) and becomes a society driven process. Conservation and management principles are still evolving, as best exemplified in the Nara Plus 20 Document. This approach-the care of heritage pursuing the well-being of both heritage and society as a whole-is tantamount to a paradigm shift within the heritage discourse and can be credited to desecularization.

\section{Sustaining De-secularisation}

There is a need to understand and sustain de-secularisation-led changes. This is challenging since the majority of heritage practitioners are grounded in the secularisationled approach, and its authority continues to play a key role in conservation and management practice. On the other hand, it is recognised that some of these themes and ideas are in the early stages of development and only have a history of two decades. This chapter describes some of the activities currently in progress for promoting these themes and ideas. While promoting them, opportunities are being used to test them through innovative methods used in various capacity building activities. 
HERITAGE MANAGEMENT (PCA)

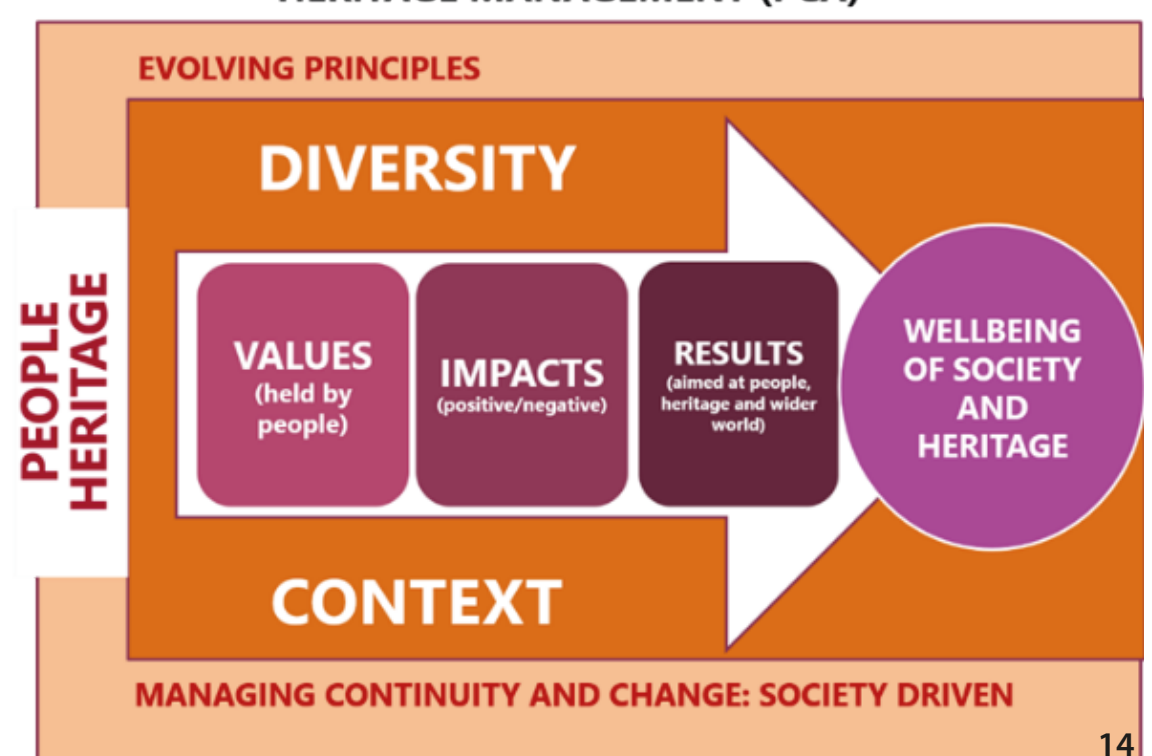

Figure 14 Approach to Management of 14 Heritage (Source: Wijesuriya 2016b).

\section{Course on People-centred Approaches to Con- servation and Management of Heritage}

As mentioned before, the Living Heritage Approach aimed at a people-led process for dealing with living heritage sites. Lessons learned suggested that people are an integral part of heritage and that their engagement is crucial in all forms of conservation practices. For this reason, ICCROM developed a programme for promoting PCA to Conservation and Management of Heritage. One of its key outcomes was the course on promoting PCA to Conservation first implemented in 2015. The two-week course while focusing on the above mentioned paradigm shift, addresses the justification for this approach, the importance of engaging communities (a core component of the course), benefits to the heritage as well as communities, issues of rights, sustainable development and the application of traditional knowledge systems in conservation practice. During the course, tools on how to engage communities are shared and discussed. In essence, the course responds to all the changes mentioned in the previous chapter. The natural heritage sectors has also recognised the PCA as a way forward and on that basis, the two courses already implemented have been extended to practitioners from the natural heritage sector.

\section{Management Systems/Planning}

In addition to the above, several attempts are made to promote and sustain the de-secularisation approach. In general, conservation literature focuses on the well-being of heritage and more particularly on prolonging the life of the fabric as described in Figure 1. However, the new resource manual on Managing Cultural World Heritage led by UNESCO (Wijesuriya et al. 2013) deviates from this approach and helps promote de-secularisation as described in Figure 14. The manual is also the first ever attempt to conceptualise heritage management systems as illustrated in the Figure 15. It describes three key elements, three processes and three types of results that constitute any management system, details of which heavily depends on a given context. The manual describes the role of each component in heritage management that also focuses on benefits to heritage as well as people. On the other hand, one can use the nine components to assess the adequacy or to understand gaps in a particular management system in order to accommodate the changes occurring (De Caro et al. 2012). The manual emphasises that the management planning process for heritage should take place within a given management system and not in isolation. Therefore, while focusing more on management systems, the manual provides guidance for management planning using a values led approach focusing on the well-being of both heritage and people. Based on this, a curriculum for a twoweek course has been designed and implemented by the WHITRAP in Shanghai.

\section{Capacity Building}

Another key concept introduced recently to support and sustain the new approach and to sustain de-secularisation is 'capacity building' which moves beyond conventional 'training' (Logan et al. 2016, Wijesuriya et al. 2017). 'capacity building' focuses on areas where capacity for conservation 


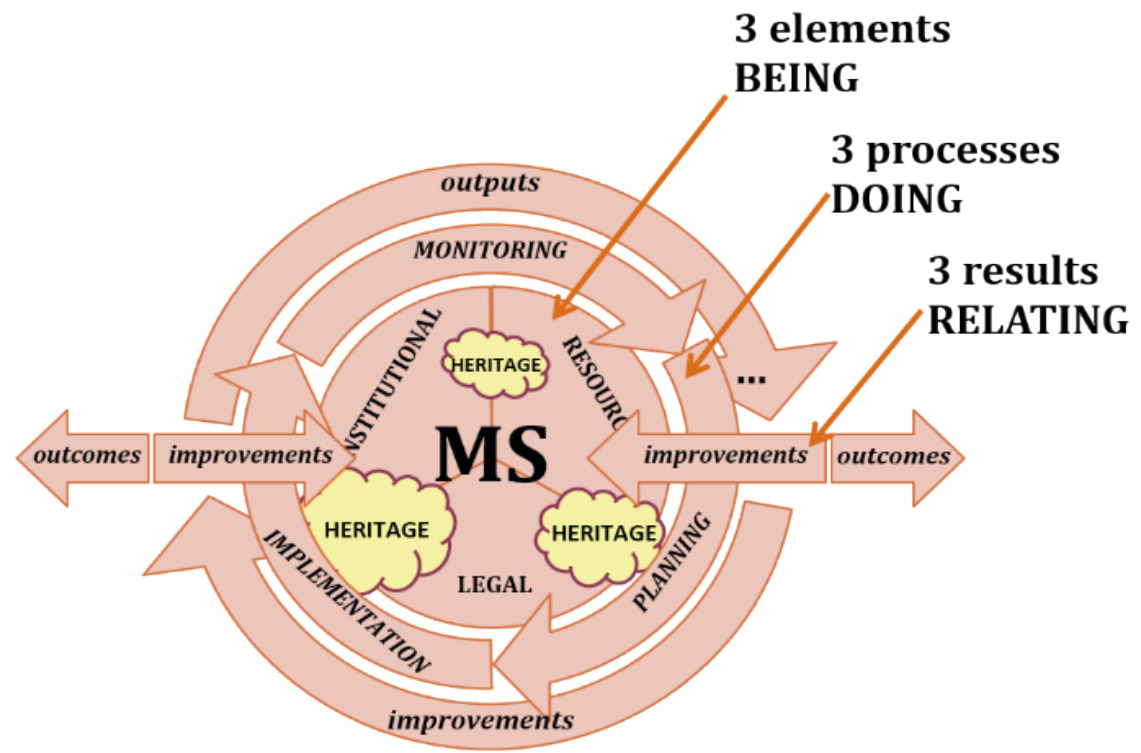

9 components

3 elements, 3 process and 3 results

Figure 15 Management System (Source: 15 Wijesuriya et al. 2013).

and management of heritage reside and addresses respective target audiences. The capacity building concepts have come from the development sector. The United Nations Development Programme (UNDP) sees capacity building (development) as the process through which individuals, organisations and societies obtain, strengthen and maintain the capabilities to set and achieve their own development objectives over time ${ }^{2}$. This concept has been translated into the heritage sector in the World Heritage Capacity Building Strategy (2011) developed by ICCROM with its partners. It is considered that the capacities for effective management of heritage reside in practitioners, institutions and communities \& networks. The respective audiences whose capacities need to be strengthened have been identified. They are the individuals directly involved, key policy and decision makers and all those affected by conservation decisions. In order to sustain the changes mentioned in the previous section, there is a need to strengthen the capacities of all audiences. The necessary guidances are provided within the World Heritage strategy for individual countries to develop their own plans for capacity building of all audiences. Such an exercise would also give the opportunity to assess the adequacy of human resources to face the new changes.

\section{New Learning Areas}

Apart from the three specific examples mentioned above, ICCROM together with other partners such as UNESCO, IUCN, ICOMOS and WHITRAP have developed a series of capacity building activities with a view to strengthening the knowledge, skills and awareness of all audiences. Some examples are the courses and workshops on Management Planning, Monitoring World Heritage, Heritage Impact Assessments, Linking Nature and Culture, Heritage and Sustainable Development, and Application of Traditional Management Systems. All of them contain elements of supporting and sustaining the de-secularisation of heritage (www.iccrom.org).

\section{Conclusions}

This paper was originally presented at a symposium titled 'Built Heritage as a Motivator for Urban and Rural Development'. Rural or urban development is about improving the quality of life and well-being of people while maintaining economic, social and environmental dimensions. In order to act as a motivator for such a development, the built heritage has to be understood not just as fabric but something that has a dynamic relationship with people. This paper argues that there are two stumbling blocks to realising this goal: one is secularisation and the other is its ongoing dominance or authority, as a result of which, many concerns of people were distanced from heritage. This was identified as the conventional (or fabric-focused) approach.

The paper however, does not discuss solutions to reduce the impacts of the two stumbling blocks, but explores and 

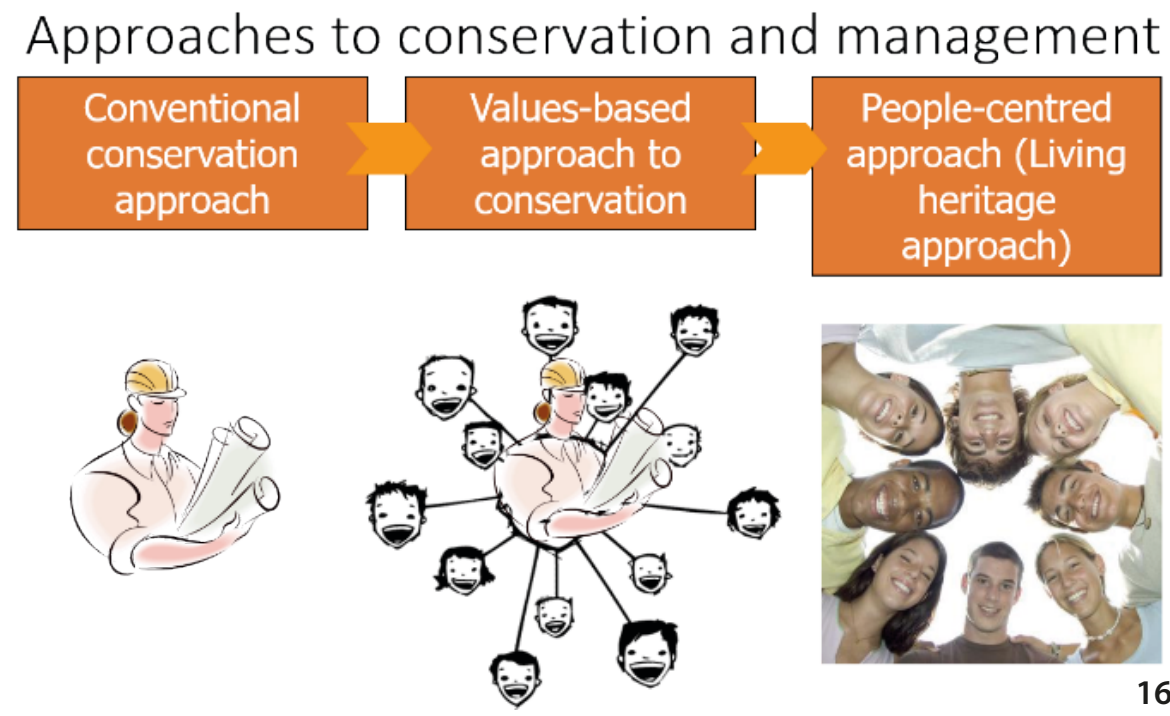

Figure 15 Evolution of approaches to conservation and management (Source: 16 Wijesuriya et al. 2017).

presentes various changes that can be considered as desecularisation that will bring people into focus. This will allow built heritage to become a motivator for development. It is also shown that the dominance or the authority of the secularisation approach is also easing to some extent. There are evident changes over the last two decades that have captured the concerns of people and integrated them into conservation and management practice. The values-led approach, the living heritage approach, and the people-centred approach were discussed briefly with a view to demonstrating their focus on people. Engaging communities, concerns with their rights, sustainable development and application of traditional knowledge systems were key components of those approaches which are being accepted and discussed widely. This paper also argues for the need to sustain and promote these approaches among a new generation and presented several available options. A people-centred approach is about capturing all values and can be considered as a natural extension to other ongoing approaches as reflected in Figure 16 (Wijesuriya et al. 2017).

The final conclusion introduced the emphasis on the new paradigm shift: 'from the care of heritage to that of pursuing the well-being of both heritage and society as a whole' and for practical purpose, promoting people-centred approach to conservation. A people-centred approach is not simply a question of increasing participation within a given management system. It is about addressing a core component of heritage management, i.e. the people connected to heritage. It is about ensuring that this integral element of heritage is at the core of heritage management practice and ensuring heritage has a dynamic and mutually beneficial role in society today and far into the future'.

\section{Notes}

1. Oxford dictionary defines secularisation (secularization) as 'the act or process of removing the influence or power that religion has over something. According to Wikipedia, 'secularization refers to the historical process in which religion loses social and cultural significance. As a result of secularization the role of religion in modern societies becomes restricted. In secularized societies faith lacks cultural authority, and religious organizations have little social power'. (https://en.wikipedia.org/ wiki/Secularization). The free dictionary defines secularisation as 'the activity of changing something (art or education or society or morality etc.) so it is no longer under the control or influence of religion' (www.thefreedictionary.com/secularisation).

2. http://www.cadri.net/en/areas-we-work/capacity-development

\section{References}

Araoz, Gustavo. 2011. "Preserving Heritage Places under a New Paradigm", Journal of Cultural Heritage Management and Sustainable Development 1(1): 55-60.

Bandarin, Francesco, and Ron Van Oers. 2012. The Historic Urban Landscape: Managing Heritage in an Urban Century. West Sussex: Willey-Blackwell.

Brandi, Cesare. 2005. Theory of Restoration. Florence: Nardini Editore.

Council of Europe. 2005. Council of Europe Framework Convention on the Value of Cultural Heritage for Society (Faro Convention). Accessed May 302017. http://www.coe.int/en/web/conventions/full-list/-/ 
conventions/rms/0900001680083746.

De Caro, Stefano, and Gamini Wijesuriya. 2012. "Engaging Communities: Approaches to Capacity Building." In Involving Communities in World Heritage Conservation-Concepts and Actions in Asia, edited by UNESCO World Heritage Centre, 48-55. Seoul: ICOMOS-KOREA.

ICCROM. 2005. Report on Living Heritage Sites Programme, First Strategy Meeting of 2003 (internal report).

ICOMOS. 1964. International Charter for The Conservation and Restoration of Monuments and Sites (The Venice Charter 1964). Accessed May 30 2016. http://www. icomos.org/charters/venice_e.pdf

ICOMOS. 1990. "ICOMOS, A Quarter of A Century, Achievements and Future prospects". $9^{\text {th }}$ ICOMOS General Assembly and International Symposium. Symposium papers. The Swiss National Committee of ICOMOS, Bern. Accessed May 30 2017. http://openarchive.icomos.org/view/collection/scientific=5Fsym posium/1990,_9th.html

ICOMOS 1994. The Nara Document on Authenticity. Accessed May 30 2017. http://www.icomos.org/charters/ nara-e.pdf

JAPAN ICOMOS 2004. Nara+20: On Heritage Practices, Cultural Values, and the Concept of Authenticity. Accessed May 30 2017. http://japan-icomos.org/pdf/ nara20_final_eng.pdf

Jokilehto, Jukka. 2015. “Conservation Ethics from Riegl's Time to the Present". Модерна Конзервација [Modern Conservation], 50: 1965-2015 (3): 11-23.

Larsen, Knute, and Nils Marstein, eds. 1994. Conference on Authenticity in Relation to the World Heritage Convention: Preparatory Workshop. Bergen: Tapir Publishers.

Logan, William, and Gamini Wijesuriya. 2015. "New Heritage Studies and Education, Training, and CapacityBuilding”. In A Companion to Heritage Studies, edited by William Logan, Máiréad Nic Craith, and Ullrich Kockel, 557-573. West Sussex: Wiley-Blackwell.

Marshall, John. 1923. Conservation Manual. Calcutta: Superintendent Government Printing.

Ndoro, Webber, and Pascal Taruvinga. 2003. "The Vandalism of Domboshava Rock Painting Site, Zimbabwe-Some Reflections on Approaches to Heriateg Managemnt". Conservation and Management of Archaeological Sites, 6: 3-10.

Ndoro, Webber, and Gamini Wijesuriya. 2015. "Heritage Management and Conservation: From Colonization to
Globalization". In Global Heritage: A Reader, edited by Lynn Meskel, 131-149. West Sussex: Wiley-Blackwell.

Paranavitana, Senarath. 1947. Protection of Monuments Other Than Those on Crown Land. Colombo: Department of Archaeology.

"Recommendations of the Madrid Conference in 1904". 1904.The Architectural Journal (Being the Journal of the Royal Institute of British Architects) 11: 343-346. Accessed March 27 2017. http://www.getty.edu/conservation/publications_resources/research_resources/ charters/charter01.html

Tomaszewski, Andrzej. 2007. "Conservation: Its Future as Discipline and Its Theory". In Cultural Heritage in the $21^{\text {st }}$ Century: Opportunities and Challenges, edited by M.A. Murzyn and J. Purchla, 163-170. Krakow: International Cultural Centre.

Silva, Roland. 1994. "The Significance of the Venice International Charter for the Conservation and Restoration of Monuments and Sites, with Special Reference to Eastern Countries". ICOMOS Scientific Journal (The Venice Charter - La Charte de Venise 1964-1994): 4044.

Silva, Roland. 1983. “The Significance of the International Venice Charter for the Conservation and Restoration of Monuments and Sites with Special Reference to Eastern Countries". In First International Congress on Architectural Conservation, Basle, Ancient Ceylon, 35. UNESCO. 1976. Recommendation Concerning the Safeguarding and Contemporary Role of Historic Areas. Accessed May 30 2017. http://portal.unesco. org/en/ev.php-URL_ID=13133\&URL_DO=DO_ TOPIC\&URL_SECTION=201.html

UNESCO. 2011. Recommendation on the Historic Urban Landscape. Accessed May 30 2017. http://portal.unesco.org/en/ev.php-URL_ID=48857\&URL_DO=DO_ TOPIC\&URL_SECTION=201.html

UNESCO. 2012. Kyoto Vision. Accessed May 302017. http://whc.unesco.org/en/news/953

UNESCO. 2013. State of Conservation of World Heritage Properties Inscribed on the List of World Heritage in Danger WHC-13/37.COM/7A. Accessed May 302017. http://whc.unesco.org/archive/2013/whc13-37com7A-en.pdf

UNESCO 2015. Policy for the Integration of a Sustainable Development Perspective into the Processes of the World Heritage Convention. Accessed May 30 2017. http:// whc.unesco.org/document/139146

UNESCO, ICOMOS, ICCROM. 2010. Preparing World Heritage Nominations. 1st ed. Paris: UNESCO 
Publication (PDF Version).

UNESCO, ICOMOS, ICCROM. 2011. Preparing World

Heritage Nominations. 2nd ed. Paris: UNESCO Pub-

lication. http://whc.unesco.org/en/preparing-world-

heritage-nominations/ accessed 30 June 2017

Wijesuriya, Gamini, Jane Thompson, and Christopher Young. 2013. UNESCO, ICOMOS, ICCROM Resource Manual on Managing Cultural World Heritage. Paris: UNESCO Publication.

Wijesuriya, Gamini, Jane Thompson, and Sarah Court. 2017. "People-centred Approaches: Engaging Communities and Developing Capacities for Managing Heritage". In Heritage, Conservation and Communities: Engagement, Participation and Capacity Building, edited by G. Chitty, 34-50. London: Routledge.

Wijesuriya, Gamini. 2000. "Conserving the Temple of the Tooth Relic, Sri Lanka." Public Archaeology 1(2): 99109.

Wijesuriya, Gamini. 2005. "Past Is in the Present: Perspectives in Caring for Buddhist Heritage Sites in Sri Lanka." In Conservation of Living Religious Heritage edited by Stovel, Herb, Nicholas Stanley-Price, and Robert Killick, 31-43. Rome: ICCROM.

Wijesuriya, Gamini. 2010. "Conservation in Context." In Proceedings of the International Conference on Conservation and Preservation-Interaction between Theory and Practice, in Memoriam Alois Riegl (1858-1905), edited by Falser, S. Michael, Wilfried Lipp, and Andrzej Tomaszewski, 233-248. Florence: Edizioni Polistampa.

Wijesuriya, Gamini. 2015. "Living Heritage: A Summary". Accessed May 30 2017. http:// www.iccrom.org/wpcontent/uploads/PCA_Annexe-1.pdf

Wijesuriya, Gamini. 2016a. "From Venice Charter to Nara+20: Beyond Heritage Secularization." Paper presented at the International Symposium on the Conservation of Brick Monuments at World Heritage Sites, Ayutthaya, October 19-21.

Wijesuriya, Gamini. 2016b. "Global Trends in Human Resources Development in Protection of Cultural Heritage". Paper presented at International Conference on Human Resources Development, Nara, Japan. 